\title{
A COMPREHENSIVE ENERGETIC, EXERGETIC AND HEAT TRANSFER ANALYSIS OF A SOLAR ORGANIC RANKINE SYSTEM
}

\author{
ABSTRACT \\ A. E. Achiles, \\ and J. V. H. d'Angelo \\ University of Campinas \\ Department of Chemical Systems Engineering \\ School of Chemical Engineering \\ Av. Albert Einstein, 500, Bloco A \\ CEP: 13083 - 852, Campinas, São Paulo, Brasil \\ a211805@dac.unicamp.br \\ dangelo@unicamp.br \\ "Corresponding Author \\ Received: Dec 07, 2020 \\ Revised: Dec 27, 2020 \\ Accepted: Fev 02, 2021 \\ Environmental concerns have been motivating the use of renewable \\ energy sources to meet sustainable requirements. In this context, \\ concentrated solar power driven by organic Rankine cycles has been \\ classified as an up-and-coming technology to generate energy under low \\ and moderate temperatures. In order to have a better understanding of the \\ availability and utilization of this energy resource, the purpose of the \\ present study is to perform a comprehensive energetic, exergetic and \\ heat transfer analysis of a $200 \mathrm{~kW}$ solar organic Rankine cycle through the \\ presentation of the energy and exergy efficiencies and losses for each \\ component; the exergy destruction at all stages of the process; and the heat \\ transfer behavior along the receiver. The thermal model was developed in \\ Engineering Equation Solver and validated with literature data. The \\ solar collector was operated with Therminol 66 and the working fluid \\ employed in the power block was cyclohexane. The energetic efficiencies \\ achieved in the solar field, power block, and overall system were 64.97; \\ 21.36 ; and $13.87 \%$, respectively. Considering the exergetic efficiencies, they \\ were $27.37 ; 54.45$; and $14.89 \%$, respectively. The solar resource variation \\ showed that the higher DNI value, the better the system performance. \\ Keywords: solar organic Rankine cycle, energetic efficiency, exergetic \\ efficiency, exergy destruction
}

\section{NOMENCLATURE}

\begin{tabular}{|c|c|}
\hline$A_{\text {ap }}$ & aperture area, $\mathrm{m}$ \\
\hline CSP & concentrating solar power \\
\hline$d_{i}$ & inside diameter, $\mathrm{m}$ \\
\hline DNI & direct normal radiation, W. $\mathrm{m}^{-2}$ \\
\hline EES & Engineering Equation Solver \\
\hline ex & specific physical exergy, $\mathrm{kJ} \mathrm{kg}^{-1}$ \\
\hline$\dot{E} x$ & exergy rate, $\mathrm{kW}$ \\
\hline $\mathrm{f}$ & friction factor \\
\hline $\mathrm{h}$ & specific enthalpy, kJ.kg-1 \\
\hline HTF & heat transfer fluid \\
\hline $\mathrm{L}$ & receiver tube length, $\mathrm{m}$ \\
\hline$\dot{\mathrm{m}}$ & mass flow rate, $\mathrm{kg} \cdot \mathrm{s}^{-1}$ \\
\hline NREL & National Renewable Laboratory \\
\hline ORC & organic Rankine cycle \\
\hline $\mathrm{P}$ & pressure, $\mathrm{Pa}$ \\
\hline PTC & parabolic trough collector \\
\hline$\dot{Q}$ & heat rate, $\mathrm{kW}$ \\
\hline $\operatorname{Re}$ & Reynolds number \\
\hline s & specific entropy, $\mathrm{kJ} \cdot \mathrm{kg}^{-1} \cdot \mathrm{K}^{-1}$ \\
\hline SORC & solar organic Rankine cycle \\
\hline $\mathrm{T}$ & temperature, $\mathrm{K}$ \\
\hline $\mathrm{v}$ & velocity, $\mathrm{m} \cdot \mathrm{s}^{-1}$ \\
\hline$\dot{\mathrm{W}}_{\text {net }}$ & power net, $\mathrm{kW}$ \\
\hline
\end{tabular}

\author{
Greek symbols

$\begin{array}{ll}\Delta & \text { variation } \\ \eta & \text { efficiency, } \% \\ \rho & \text { density, kg.m }{ }^{-3}\end{array}$

\section{Subscripts}

$\begin{array}{ll}\text { abs } & \text { absorbed } \\ \text { block } & \text { power block } \\ \text { cond } & \text { conduction or condenser } \\ \text { conv } & \text { convection } \\ \mathrm{d} & \text { destruction } \\ \text { en } & \text { energetic } \\ \text { env } & \text { environment } \\ \text { evap } & \text { evaporator } \\ \text { ex } & \text { exergetic } \\ \text { g } & \text { glass cover } \\ \text { in } & \text { inlet } \\ \text { isent } & \text { isentropic } \\ \text { loss } & \text { loss } \\ \text { min } & \text { minimum } \\ \text { opt } & \text { optical } \\ \text { out } & \text { outlet } \\ \text { overall } & \text { overall }\end{array}$




$\begin{array}{ll}\mathrm{p} & \text { pump } \\ \mathrm{r} & \text { receiver } \\ \mathrm{rad} & \text { radiation } \\ \mathrm{ref} & \text { reference } \\ \mathrm{r}-\mathrm{HTF} & \text { between the receiver and HTF } \\ \text { sky } & \text { sky } \\ \text { solar } & \text { solar field } \\ \text { s-r } & \text { between the sun and the receiver } \\ \text { sun } & \text { sun } \\ \text { th } & \text { thermal }\end{array}$

\section{INTRODUCTION}

Solar energy usage for power generation is one of the most promising alternatives for facing global problems as the climate change, increased $\mathrm{CO}_{2}$ emissions, fossil fuel depletion and growth of energy demand. One of the available options for power generation by employing solar radiation is converting its energy into heat and electrical energy. This technology is named as concentrating solar power (CSP), that is mainly composed by a solar field, where the solar radiation is collected and concentrated, and a power block, in which electricity is generated (Heller, 2017).

Among the feasible technologies to concentrate solar radiation in the solar field, parabolic trough collector (PTC) is the most mature one. It is able to produce heat at temperatures up to $400{ }^{\circ} \mathrm{C}$ with better cost-effective and developed performance (Kalogirou, 2012). Considering the power block, solar organic Rankine cycle (SORC) has proven to be an effective thermodynamic power system to apply solar thermal energy since it can bring about several benefits like: effectiveness in harnessing solar energy in lowmedium temperatures; fluid superheat is not required; more stability of power generation for a wide solar radiation range; good applicability in regions without rich direct solar resource; and reduced operation pressure in the power block (Aboelwafa et al., 2018).

The evaluation of the thermodynamic performance of a solar power plant in terms of energy and exergy analysis may result in the identification of a proper effective configuration, giving a better understanding to determine the quality, availability and utilization of energy resources. The energy (First Law) analysis provides the quantitative energy losses involved in various components of a power plant, whereas the exergy (Second Law) one supplies the qualitative energy losses. Also, the exergy analysis enables the evaluation of the magnitude of various losses in each component of the system (Ravi Kumar and Reddy, 2012).

Over the years, solar organic Rankine cycles have extensively been reported in the literature. Techanche et al. (2009) investigated the thermodynamic performance of a SORC by employing 20 different organic fluids. Rayegan and Tao (2018) elaborated a procedure in order to identify the potential of 117 organic fluids on SORC operation in terms of energy and exergy efficiencies. Yang et al. (2019) proposed an original operation method to a SORC, based on thermodynamic analysis, with the purpose of generating stable output power.

Although there is a considerable number of studies that cover this research area, it was observed that there is still a lack regarding research that analyze this subject thoroughly by considering both thermodynamic and heat transfer performances. Thus, the objective of this paper is to contribute with a thermodynamic investigation of a SORC by taking into account the energetic and exergetic efficiencies for each component of the system (solar field, power block and overall plant); the exergy losses and destruction at all stages of the process; as well as carrying out a heat transfer analysis on the receiver tube heat losses, temperature and pressure drop profiles. In addition, it was performed an assessment of the system performance under DNI variation.

\section{METHODOLOGY}

The system under analysis consists of a $200 \mathrm{~kW}$ SORC as presented in Fig.1.

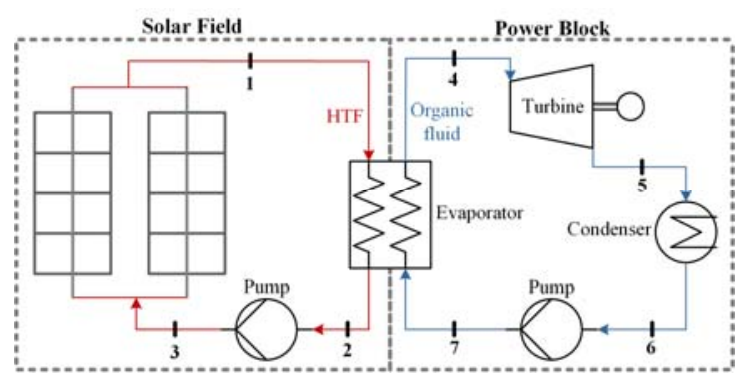

Figure 1. Schematic of SORC power system.

The solar field includes PTC collectors and Therminol 66 as heat transfer fluid (HTF). The design direct normal radiation (DNI) considered was 717.2 W. $\mathrm{m}^{-2}$, which was based on the climatological data from Bom Jesus da Lapa (BA) in Brazil and estimated according to National Renewable Energy Laboratory (NREL) guide.

The organic fluid chosen to drive the power block was cyclohexane since it is classified as a dry fluid so that it does not require superheating; also it has presented an outstanding thermodynamic performance in several studies like Shu et al. (2014); Fergani et al. (2016); and Rayegan and Tao (2018).

The mathematical model of the proposed system was developed in Engineering Equation Solver (EES) and its choice is due to the fact that this software has been used worldwide and contains trustworthy routines to estimate the physical and thermodynamic properties of diverse substances. 
Table 1 presents the values assumed for each input variable in the simulation.

Table 1. Input variables adopted for the simulation.

\begin{tabular}{cccc}
\hline Variable & Symbol & Value & Unit \\
\hline $\begin{array}{c}\text { HTF evaporator inlet } \\
\text { temperature } \\
\text { ORC turbine inlet } \\
\text { temperature }\end{array}$ & $\mathrm{T}_{1}$ & 295 & ${ }^{\circ} \mathrm{C}$ \\
$\begin{array}{c}\text { ORC condenser outlet } \\
\text { temperature } \\
\text { Minimum temperature } \\
\text { difference in the } \\
\text { evaporator and the } \\
\begin{array}{c}\text { condenser } \\
\text { Turbine and pumps }\end{array}\end{array}$ & $\mathrm{T}_{4}$ & 250 & ${ }^{\circ} \mathrm{C}$ \\
isentropic efficiencies & $\mathrm{T}_{6}$ & 50 & ${ }^{\circ} \mathrm{C}$ \\
\hline min & 10 & ${ }^{\circ} \mathrm{C}$ \\
\hline
\end{tabular}

\section{Solar field heat transfer model}

The heat collection element is composed by two concentric tubes: a stainless-steel receiver, through which HTF flows, surrounded by a glass envelope. Among them there is an evacuated region called annulus in order to reduce heat losses. Thus, the collector model uses an energy balance between the fluid flowing through the receiver and the atmosphere. It includes all equations necessary to predict the various expressions which depend on the ambient conditions and the collector receiver optical properties.

The overall solar energy rate focused on the surface area of the collectors is given by Eq. (1).

$$
\dot{\mathrm{Q}}_{\text {solar }}=\mathrm{A}_{\mathrm{ap}} \mathrm{DNI}
$$

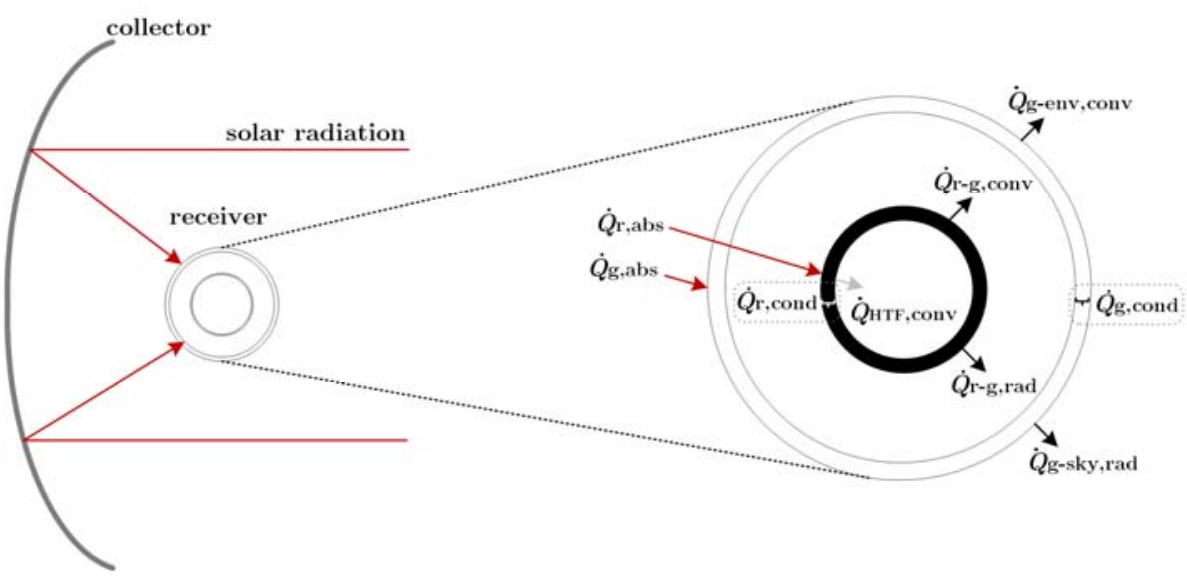

Figure 2. Heat transfer mechanisms in the cross-section of the receiver tube.

The energy balance equations are determined by considering that the energy is conserved at each surface of the receiver cross-section, shown in Fig. 2. Therefore: where $A_{a p}$ is the collector aperture area.

However, due to the optical losses caused by imperfections in the collector's mirrors, tracking errors, shading and cleanliness of the mirror and receiver glazing, only a portion of the overall energy will be absorbed by the heat element. Equations (2) and (3) show the heat absorbed rate by the receiver and glass envelope, respectively.

$$
\begin{aligned}
& \dot{\mathrm{Q}}_{\mathrm{r}, \mathrm{abs}}=\eta_{\mathrm{r}} \mathrm{A}_{\mathrm{ap}} \mathrm{DNI} \\
& \dot{\mathrm{Q}}_{\mathrm{g}, \mathrm{abs}}=\eta_{\mathrm{g}} \mathrm{A}_{\mathrm{ap}} \mathrm{DNI}
\end{aligned}
$$

where $\eta_{\mathrm{r}}$ and $\eta_{\mathrm{g}}$ are the optical efficiencies of the receiver and glass envelope, respectively.

The heat transfer in a receiver cross section, as demonstrated by Fig. 2, is given by: solar energy reflected by the mirrors is most absorbed by the receiver $\left(\dot{Q}_{r, a b s}\right)$ and an insignificant quantity is collected by the glass envelope $\left(\dot{\mathrm{Q}}_{\mathrm{g}, \mathrm{abs}}\right)$. Part of the energy absorbed into receiver outer surface is transferred to its inner surface by conduction $\left(\dot{Q}_{r, \text { cond }}\right)$ and then to HTF by forced convection $\left(\dot{\mathrm{Q}}_{\mathrm{HTF}, \text { conv }}\right)$ to increase its energy content until it achieves the required temperature. The energy that remains is transferred back to the glass envelope inner surface by radiation $\left(\dot{\mathrm{Q}}_{\mathrm{r}-\mathrm{g}, \mathrm{rad}}\right)$ and natural convection ( $\dot{\mathrm{Q}}_{\mathrm{r}-\mathrm{g} \text {,conv }}$ ), and passes through the glass envelope by conduction ( $\left.\dot{\mathrm{Q}}_{\mathrm{g}, \mathrm{cond}}\right)$. Then it is lost to the environment by convection ( $\left.\dot{\mathrm{Q}}_{\mathrm{g}-\mathrm{env}, \mathrm{conv}}\right)$ and to sky by radiation $\left(\dot{\mathrm{Q}}_{\mathrm{g}-\mathrm{sky}, \mathrm{rad}}\right)$.

$$
\begin{gathered}
\dot{\mathrm{Q}}_{\mathrm{HTF}, \text { conv }}=\dot{\mathrm{Q}}_{\mathrm{r}, \text { cond }} \\
\dot{\mathrm{Q}}_{\mathrm{r}, \mathrm{abs}}=\dot{\mathrm{Q}}_{\mathrm{r} \text {,cond }}+\dot{\mathrm{Q}}_{\mathrm{r}-\mathrm{g}, \text { conv }}+\dot{\mathrm{Q}}_{\mathrm{r}-\mathrm{g}, \mathrm{rad}} \\
\dot{\mathrm{Q}}_{\mathrm{g}, \text { cond }}=\dot{\mathrm{Q}}_{\mathrm{r}-\mathrm{g}, \text { conv }}+\dot{\mathrm{Q}}_{\mathrm{r}-\mathrm{g}, \mathrm{rad}}
\end{gathered}
$$




$$
\dot{Q}_{H T F, \text { conv }}=\dot{Q}_{H T F}
$$

The term $\dot{\mathrm{Q}}_{\mathrm{HTF}}$ refers to the useful heat rate delivered to HTF in the solar field and can be determined through:

$$
\dot{\mathrm{Q}}_{\mathrm{HTF}}=\dot{\mathrm{m}}_{\mathrm{HTF}}\left(\mathrm{h}_{\mathrm{HTF}, \text { out }}-\mathrm{h}_{\mathrm{HTF}, \text { in }}\right)
$$

in which $\dot{\mathrm{m}}_{\mathrm{HTF}}$ is the HTF mass rate; $\mathrm{h}_{\mathrm{HTF} \text {,in }}$ and $\mathrm{h}_{\mathrm{HTF}, \text { out }}$ are the inlet and outlet HTF specific enthalpies in the receiver, respectively.

In order to determine the HTF pressure drop along the receiver tube, it was employed Eq. (10) applied for turbulent flow (Bellos et al., 2016).

$$
\Delta \mathrm{P}=\mathrm{f} \frac{\mathrm{L}}{\mathrm{d}_{\mathrm{i}, \mathrm{r}}}\left(\frac{1}{2} \rho_{\mathrm{HTF}} \mathrm{V}_{\mathrm{HTF}}^{2}\right)
$$

where $\mathrm{L}$ and $\mathrm{d}_{\mathrm{i}, \mathrm{r}}$ are the receiver tube length and inside diameter, respectively; $\rho_{\mathrm{HTF}}$ and $\mathrm{V}_{\mathrm{HTF}}$ are the HTF density and velocity, respectively; and $\mathrm{f}$ is the friction factor obtained by using Eq. (11).

$$
f=\frac{1}{[0.79 \ln (\operatorname{Re})-1.64]^{2}}
$$

The model assumes steady state and that all temperatures, heat fluxes, and thermodynamic properties are uniform around the circumference of the receiver, as well as it was validated with experimental data obtained from Sandia National Laboratory (Dudley et al., 1994). Its detailing is included in Kalogirou (2012).

\section{Power block thermodynamic model}

The thermodynamic model of the power cycle was established by the mass and energy conservation principles in each component taking into account the following assumptions: steady state; pressure drops in pipes and heat exchangers were neglected; the pumps and turbine were considered adiabatic; a thermal effectiveness of $100 \%$ was adopted for both heat exchangers (evaporator and condenser); the organic fluid is fed the ORC turbine as saturated vapor and leaves the condenser as saturated liquid. Water was used to condense the organic fluid, being fed into the condenser at ambient temperature and pressure $(298.15 \mathrm{~K}$ and $101.3 \mathrm{kPa})$.

\section{Energetic efficiencies}

The system energy analysis was carried out, separately, for the solar field, power block, and overall solar power plant, which can be calculated by employing Eq. (12), (13) and (14), respectively.

$$
\begin{gathered}
\dot{\mathrm{Q}}_{\mathrm{g}, \mathrm{abs}}=\dot{\mathrm{Q}}_{\mathrm{g}, \text { cond }}+\dot{\mathrm{Q}}_{\mathrm{g}-\mathrm{env}, \mathrm{conv}}+\dot{\mathrm{Q}}_{\mathrm{g}-\mathrm{sky}, \mathrm{rad}} \\
\eta_{\text {en,solar }}=\frac{\dot{\mathrm{Q}}_{\mathrm{HTF}}}{\dot{\mathrm{Q}}_{\text {solar }}} \\
\eta_{\text {en,block }}=\frac{\dot{\mathrm{W}}_{\text {net }}}{\dot{\mathrm{Q}}_{\mathrm{HTF}}} \\
\eta_{\text {en,overall }}=\frac{\dot{\mathrm{W}}_{\text {net }}}{\dot{\mathrm{Q}}_{\text {solar }}}
\end{gathered}
$$

where $\dot{W}_{\text {net }}$ is the net power rate generated by the system.

\section{Exergetic efficiencies}

The exergy analysis was accomplished considering the solar field, power block and overall power system. The solar field exergetic efficiency can be obtained by the relation between the exergy rate absorbed by the fluid in the receiver $\left(\dot{E}_{\mathrm{HTF}}\right)$ and exergy rate received by the concentrator $\left(\dot{E x}_{\text {solar }}\right)$ :

$$
\eta_{\text {ex,solar }}=\frac{\dot{\mathrm{Ex}} \mathrm{HTF}_{\mathrm{HTF}}}{\dot{\mathrm{E} \mathrm{x}_{\text {solar }}}}
$$

The exergy rate received by the concentrator is given by Petela model (Petela, 2003), Eq. (16), that takes into account that the sun is a radiation reservoir of temperature $\left(\mathrm{T}_{\text {sun }}\right)$, which is estimated to be 5770 $\mathrm{K}$. The useful exergy rate absorbed by HTF in the receiver is determined by Eq. (17) (Bellos and Tzivanidis, 2017).

$$
\begin{aligned}
& \dot{\mathrm{Ex}}_{\text {solar }}=\dot{\mathrm{Q}}_{\text {solar }}\left[1-\frac{4}{3}\left(\frac{\mathrm{T}_{\text {ref }}}{\mathrm{T}_{\text {sun }}}\right)\right. \\
& \left.+\frac{1}{3}\left(\frac{\mathrm{T}_{\text {ref }}}{\mathrm{T}_{\text {sun }}}\right)^{4}\right] \\
& \dot{\mathrm{E}} \mathrm{x}_{\mathrm{HTF}}=\dot{\mathrm{m}}_{\mathrm{HTF}}\left(\mathrm{ex}_{\mathrm{HTF}, \text { out }}-\mathrm{ex}_{\mathrm{HTF}, \text { in }}\right)
\end{aligned}
$$

where $\mathrm{T}_{\text {ref }}$ is the temperature of the reference state, that was established in $298.15 \mathrm{~K}$ and $1 \mathrm{~atm}$, and ex refers to specific physical exergy of the substance and can be obtained by:

$$
e x=\left(h-h_{\text {ref }}\right)-T_{\text {ref }}\left(s-s_{\text {ref }}\right)
$$

where $\mathrm{s}$ is the specific entropy.

Finally, the exergetic efficiencies of the power block and the overall system can be obtained through Eq. (19) and (20), respectively. 


$$
\begin{gathered}
\eta_{\text {ex,block }}=\frac{\dot{\mathrm{W}}_{\text {net }}}{\dot{\mathrm{Ex}} \mathrm{HTF}_{\mathrm{HTF}}} \\
\eta_{\text {ex,overall }}=\frac{\dot{\mathrm{W}}_{\text {net }}}{\dot{\mathrm{E}} \mathrm{x}_{\text {solar }}}
\end{gathered}
$$

\section{Exergy losses and destruction}

To perform a detailed exergetic analysis of the solar field, the exergy losses and destruction rates have to be determined. The exergy losses are associated with the heat losses of the examined system which are not further utilized (Bellos and Tzivanidis, 2017). These losses regard the optical (Eq. 21) and thermal losses (Eq. 22).

$$
\begin{aligned}
& \dot{E} x_{\text {loss }, \text { opt }}= {\left[1-\left(\eta_{\mathrm{r}}+\eta_{\mathrm{g}}\right) \dot{\mathrm{E}} \mathrm{x}_{\text {solar }}\right] } \\
& \dot{\mathrm{E}} \mathrm{x}_{\text {loss }, \mathrm{th}}=\left(\dot{\mathrm{Q}}_{\mathrm{g}-\text { env,conv }}+\dot{\mathrm{Q}}_{\mathrm{g}-\text { sky,rad }}\right) \\
& {\left[1-\frac{\mathrm{T}_{\mathrm{ref}}}{\mathrm{T}_{\mathrm{HTF}}}\right] }
\end{aligned}
$$

The exergy destruction is related to the irreversibilities associated to heat transfers. There are two cases of exergy destruction in the solar field: between the sun and receiver (Eq. 23) and among the receiver and the heat transfer fluid (Eq. 24).

$$
\begin{gathered}
\dot{\mathrm{Ex}}_{\mathrm{d}, \mathrm{s}-\mathrm{r}}=\left(\eta_{\mathrm{r}}+\eta_{\mathrm{g}}\right) \dot{\mathrm{E}} \mathrm{x}_{\text {solar }}-\left(\dot{\mathrm{Q}}_{\mathrm{r}, \mathrm{abs}}\right. \\
\left.+\dot{\mathrm{Q}}_{\mathrm{g}, \mathrm{abs}}\right)\left[1-\frac{\mathrm{T}_{\mathrm{ref}}}{\mathrm{T}_{\mathrm{HTF}}}\right] \\
\dot{\mathrm{E}}_{\mathrm{d}, \mathrm{r}-\mathrm{HTF}}=\left(\dot{\mathrm{Q}}_{\mathrm{r}, \mathrm{abs}}+\dot{\mathrm{Q}}_{\mathrm{g}, \mathrm{abs}}\right)\left[1-\frac{\mathrm{T}_{\mathrm{ref}}}{\mathrm{T}_{\mathrm{HTF}}}\right] \\
+\dot{\mathrm{W}}_{\mathrm{p}, \mathrm{solar}}-\dot{\mathrm{E} x_{\text {loss }, \mathrm{th}}} \\
-\dot{\mathrm{E}}_{\mathrm{HTF}}
\end{gathered}
$$

where $\dot{W}_{\mathrm{p} \text {,solar }}$ is the work rate required by the pump located in the solar field.

For the other system equipments, the exergy destruction rate in each control volume can be calculated using Eq. (25).

$$
\begin{gathered}
\dot{\mathrm{Ex}}_{\mathrm{d}}=\dot{\mathrm{Q}}\left(1-\frac{\mathrm{T}_{\text {ref }}}{\mathrm{T}}\right)-\dot{\mathrm{W}}+\sum \dot{\mathrm{m}}_{\mathrm{in}} \mathrm{ex}_{\mathrm{in}} \\
-\sum \dot{\mathrm{m}}_{\text {out }} \mathrm{ex}_{\text {out }}
\end{gathered}
$$

\section{Meteorological data}

Since local DNI considerably impacts the CSP performance, this variable was also investigated. From 8760 DNI values available at Bom Jesus da Lapa database - that express an hour-base DNI during one year - it was chosen the day with the highest average daily irradiation. The daily DNI used in the simulation is exposed in Fig. 3.

In this analysis, the solar field area required for the solar field was kept fixed at the value determined for the design DNI, so that it was possible to account the net power generated for the system under the solar radiation variation.

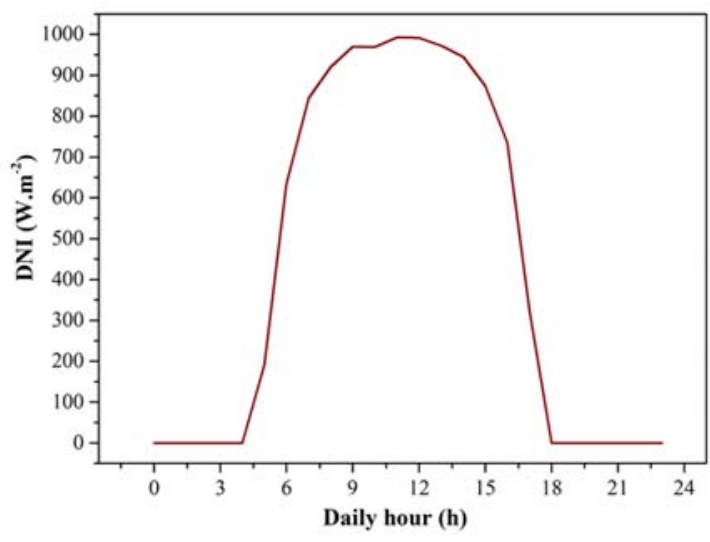

Figure 3. Daily DNI used in the simulation.

\section{RESULTS AND DISCUSSION}

In order to ensure data reliability, the heat transfer model of the solar field was validated according to Fig. 4, from which it is possible to verify that the proposed model presented a similar trend when compared to experimental data from Dudley et al. (1994). In addition, the power block was validated with Rayegan and Tao (2018) study with a reliability greater than $97 \%$.

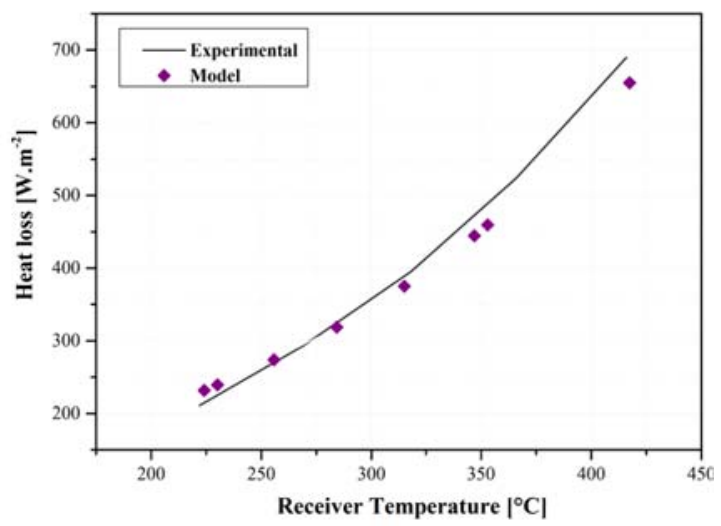

Figure 4. Solar field model validation.

\section{Thermodynamic analysis}

Table 2 and Fig. 5 present the thermodynamic properties (temperature and pressure) and mass flow rates of all streams of the proposed SORC power system and a schematic of its $T-s$ diagram, respectively. From these results, it is possible to infer that the mass flow rate required by HTF in the solar 
field was almost twice as high that one demanded by the organic fluid in the power block. The temperature rise required by the $\mathrm{HTF}$ in the receiver was equivalent to $153.6{ }^{\circ} \mathrm{C}$ (from 141.4 to $295^{\circ} \mathrm{C}$ ) and the pressure drop in the solar field was $37.6 \mathrm{kPa}$. To promote this, it was necessary a receiver tube with a total length of $356.2 \mathrm{~m}$ and an aperture area of $2011 \mathrm{~m}^{2}$.

Table 2. Thermodynamic properties and mass flow rate of all process streams.

\begin{tabular}{cccc}
\hline Stream & $\begin{array}{c}\text { Temperature } \\
{\left[{ }^{\circ} \mathrm{C}\right]}\end{array}$ & $\begin{array}{c}\text { Pressure } \\
{[\mathrm{kPa}]}\end{array}$ & $\begin{array}{c}\text { Mass } \\
\text { flow } \\
\text { rate } \\
{\left[\mathrm{kg} \cdot \mathrm{s}^{-1}\right]}\end{array}$ \\
\hline 1 & 295.0 & 110 & 2.693 \\
2 & 141.3 & 110 & \\
3 & 141.4 & 147.6 & \\
4 & 250.0 & 2766 & \\
5 & 145.2 & 36.3 & 1.381 \\
6 & 50.0 & 36.3 & \\
7 & 51.1 & 2766 & \\
\hline
\end{tabular}

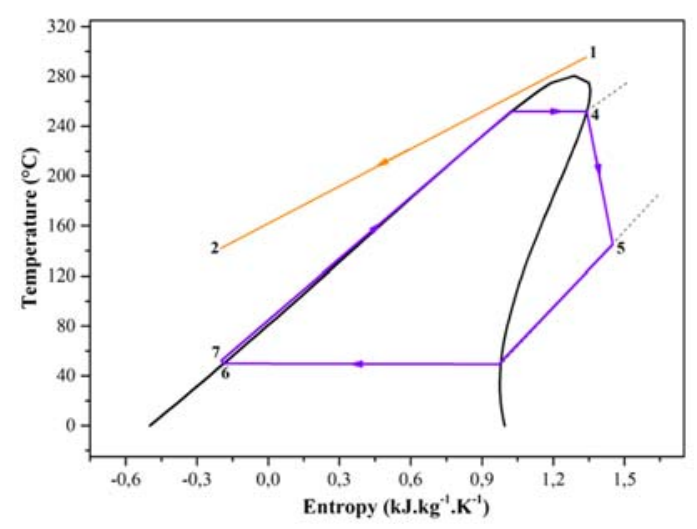

Figure 5. T-s diagram of the system.
In order to better understand the energetic flow throughout the system, Fig. 6 contains a Sankey diagram showing the main energy losses in each system component. The overall solar energy rate focused by the collectors was $1442 \mathrm{~kW}$ ( $\left.\dot{\mathrm{Q}}_{\text {solar }}\right)$.

Due to the heat losses related to the optical parameters $\left(\dot{Q}_{\text {loss,opt }}\right)$, a portion of about $1020.9 \mathrm{~kW}$ was absorbed by the heat collection element: $97.7 \%$ was absorbed by the receiver tube and only $2.3 \%$ by the glass envelope.

Because of the temperature difference between the receiver and the environment, a quantity of 84.2 $\mathrm{kW}\left(\dot{\mathrm{Q}}_{\text {loss,r }}\right)$ from the heat absorbed by the receiver was lost to surroundings $(55.5 \%$ and $44.5 \%$ by convection and radiation, respectively).

The useful heat rate delivered to HTF was 936.7 $\mathrm{kW}$, promoting to the solar field an energetic efficiency of $64.97 \%$. In the power block, all the heat HTF content was transferred to organic fluid (since the heat exchanger thermal effectiveness assumed was $100 \%$ ).

However, most of the heat rate that enters into power block is rejected to the water in the condenser $\left(\dot{Q}_{\text {loss,cond }}=736,7 \mathrm{~kW}\right)$ and the gross power generated by the turbine is simply $206.1 \mathrm{~kW}$. It caused a power block energetic efficiency of $21.36 \%$. Hence, given the complete flow at each part of the plant, the overall thermal system efficiency achieved was $13.87 \%$.

Taking the exergetic flow rate into analysis, Fig. 7 shows a Grassmann diagram to demonstrate in detail the exergy losses and destruction in the system. As can be seen, initially, the overall exergy rate available in the solar collector $\left(\dot{\mathrm{E}} \mathrm{x}_{\text {solar }}\right)$ was $1342.8 \mathrm{~kW}$.

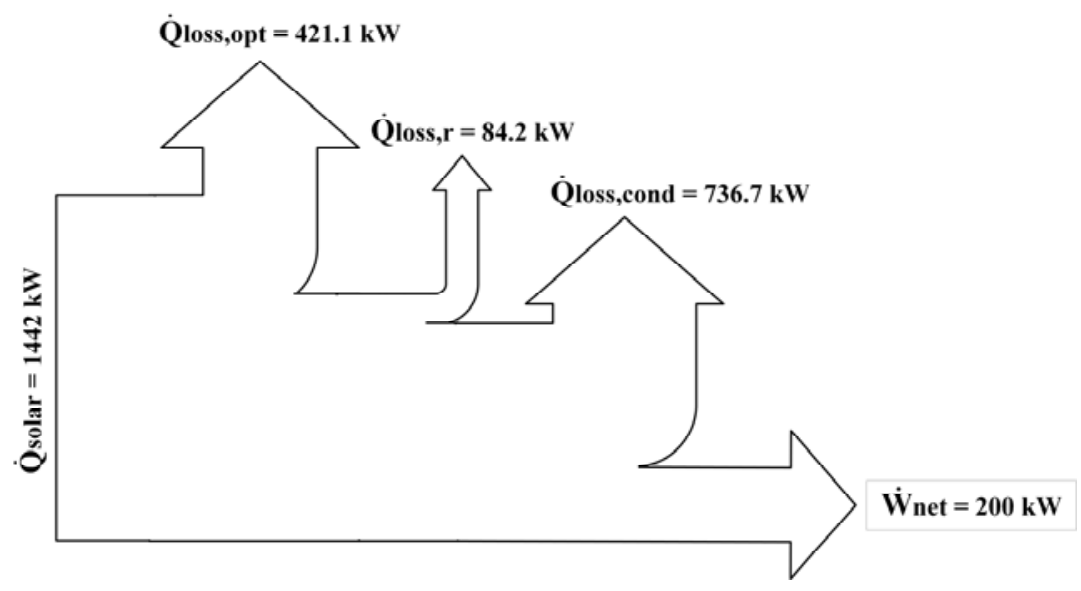

Figure 6. Sankey diagram of the system. 


\section{Ciência/Science}

Nonetheless, an amount of $40.9 \%$ was destroyed due to the temperature difference between sun and the receiver $\left(\dot{\mathrm{E}} \mathrm{x}_{\mathrm{d}, \mathrm{s}-\mathrm{r}}\right)$ and $29.2 \%$ was lost because of optical imperfections $\left(\dot{\mathrm{E}} \mathrm{x}_{\text {loss,opt }}\right)$. As a result, the exergy rate input into receiver was $401.7 \mathrm{~kW}$.

In the receiver, the thermal exergy loss rate (Éx $\left.x_{\text {loss,th }}\right)$ was the most relevant: $34.2 \mathrm{~kW}$, whereas the exergy destruction rate between the receiver and the HTF was insignificant $\left(\dot{\mathrm{E}} \mathrm{x}_{\mathrm{d}, \mathrm{r}-\mathrm{HTF}}=0.03 \mathrm{~kW}\right)$. Thereby, the useful exergy rate $\left(\dot{\mathrm{Ex}}_{\mathrm{HTF}}\right)$ transferred from the solar field to power block was $367.4 \mathrm{~kW}$ causing a solar field exergetic efficiency of $27.37 \%$.

In the power block, the total exergy losses and destruction rates (E் $\left.x_{\text {loss/d,orc }}\right)$ was $167.4 \mathrm{~kW}$. Considering this specific parameter, the exergy destruction in the evaporator and condenser accounted for, approximately, $34.4 \%$, each one; the exergy destruction in the turbine accounted for about $15.4 \%$; and the exergy loss to the water in the condenser also accounted for $15.4 \%$.

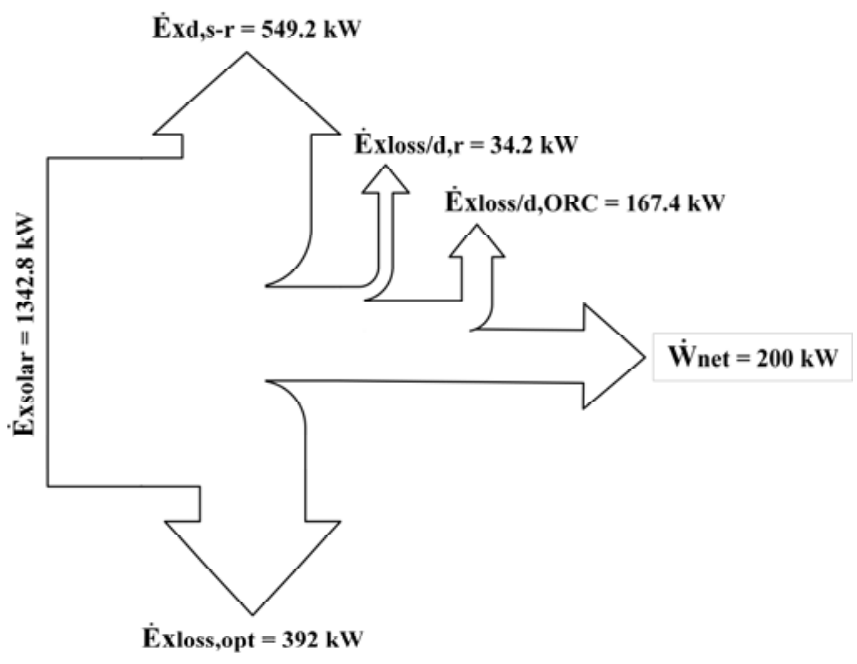

Figure 7. Grassmann diagram of the system.

The exergy destruction in the ORC pump was negligible. Since less than half of the useful exergy rate available to the power block was lost/destroyed, so that the exergetic efficiency of the power block reached $54.45 \%$.

In the interest of clarifying the exergetic analysis, Fig. 8 brings a graphic that compares the magnitude of all rates of exergy lost and destroyed in the entire system. The solar field was responsible for, approximately, $85 \%$ of all exergy lost and destroyed. The most portion of the exergy destruction rate was due to the temperature difference between the sun and the receiver and the most part of the exergy losses rate happened as a result of the optical imperfections. The rate of exergy lost because of the heat losses from the receiver to surroundings was equivalent to only $3.5 \%$ of all exergy lost and destroyed in the solar field. On the other hand, the power block just accounted for about $15 \%$ of all exergy lost and destroyed in the system. The major reason for this result may be associated to the lower operating temperatures when compared to solar field.

Also, it was assumed a value of $100 \%$ for both heat exchangers effectiveness (evaporator and condenser) which probably reduced the exergy destruction rate in these equipment.
To summarize the thermodynamic analysis, Table 3 presents the results of energetic and exergetic efficiencies of the SORC system proposed.

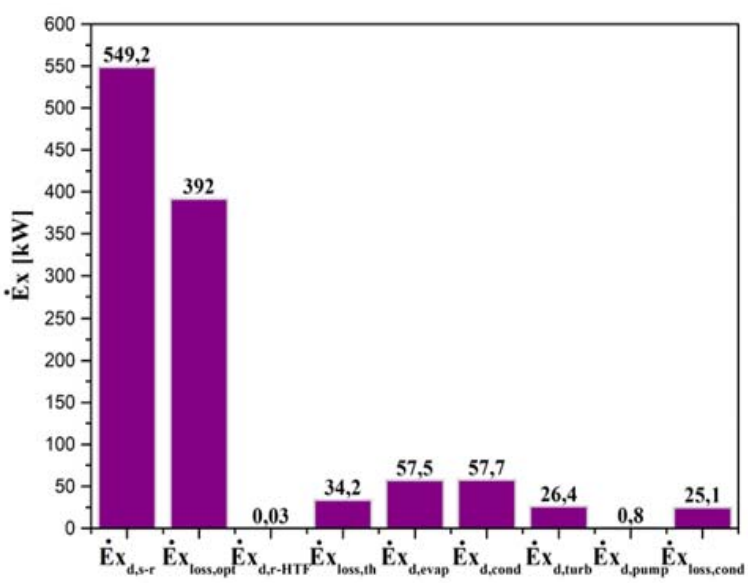

Figure 8. Exergy losses and destruction rates all over the system. 
Table 3. Energetic and exergetic efficiencies results.

\begin{tabular}{ccc}
\hline Component & $\begin{array}{c}\text { Energetic } \\
\text { efficiency [\%] }\end{array}$ & $\begin{array}{c}\text { Exergetic } \\
\text { efficiency [\%] }\end{array}$ \\
\hline Solar field & 64.97 & 27.37 \\
Power block & 21.36 & 54.45 \\
Overall system & 13.87 & 14.85 \\
\hline
\end{tabular}

\section{System operation under DNI variation}

Figure 9 shows the power net generated by the system as well as the HTF and ORC mass flow rates under a DNI variation during 24 hours of day selected from the Bom Jesus da Lapa meteorological database. As can be verified, the higher DNI value, the better the system performance. From 7 a.m. until 4 p.m., the system was able to exceed the design power of 200 $\mathrm{kW}$. The maximum generated power was $281.9 \mathrm{~kW}$, which occurred at 11 a.m. From 5 to 7 a.m. and from 5 to 6 p.m., the power generated by the system is lower than the design power.

The overall power generated was $2907 \mathrm{kWh} . \mathrm{day}^{-1}$. Following the trend of the net power, the HTF and ORC mass flow rates required by the system also enhanced with the DNI increasing. The peak of the mass flow rates was also at 11 a.m., which were equivalent to 3.798 and $1.381 \mathrm{~kg} . \mathrm{s}^{-1}$ for HTF and ORC, respectively. Regarding the energetic and exergetic performances under DNI variation.

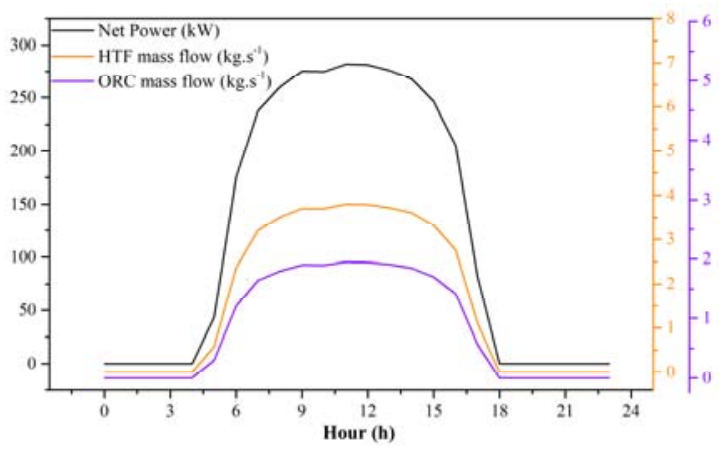

Figure 9. Net power, HTF and ORC mass flow rates under DNI variation.

Table 4 makes a comparison between the efficiencies achieved for the maximum (at 11 a.m.) and minimum (at 5 a.m.) hourly DNI.

With the exception of the energetic and exergetic efficiencies of the power block, which remained constant, all other efficiencies enhanced with the increase in the DNI value since the higher the DNI, the greater the energy and exergy available to the system. The percentage deviations were practically the same for these efficiencies: approximately $25.5 \%$. Considering the power block efficiencies, they kept the same value because of the variation on the HTF and ORC mass flow rates by the DNI change were equivalent.
Table 4. Energetic and exergetic efficiencies under DNI variation.

\begin{tabular}{ccc}
\hline $\begin{array}{c}\text { DNI } \\
{\left[\mathrm{W} . \mathrm{m}^{-2}\right]}\end{array}$ & $\begin{array}{c}993.0 \\
\text { (maximum) }\end{array}$ & $\begin{array}{c}191.0 \\
\text { (minimum) }\end{array}$ \\
\hline \multicolumn{3}{c}{ Energetic efficiency [\%] } \\
\hline Solar field & 66.17 & 52.69 \\
Power block & 21.36 & 21.36 \\
Overall & 14.12 & 13.75 \\
system & \\
\hline \multicolumn{3}{c}{ Exergetic efficiency [\%] } \\
\hline Solar field & 27.87 & 22.20 \\
Power block & 54.45 & 54.45 \\
Overall & 15.15 & 12.09 \\
system & &
\end{tabular}

\section{CONCLUSIONS}

A detailed thermodynamic and heat transfer evaluation of a $200 \mathrm{~kW}$ solar organic Rankine cycle system was carried out in this study. The analysis taken into consideration the energetic and exergetic efficiencies in each component of the system, and the exergy losses and destruction at all stages of the process. The mathematical models of the solar field and power block were developed in the EES and validated with literature data presenting reliable results. The relevant findings of the current analysis were as follows:

- The area required by the solar field was $2011 \mathrm{~m}^{2}$, and the pressure drop in the receiver tube was $37.6 \mathrm{kPa}$. - In the solar field, the most energy loss was due to the imperfections in the optical system. However, the heat rejected in the condenser was the greatest source of energy loss in the system. The energetic efficiencies achieved in the solar field, power block and overall system were $64.97 ; 21.36$; and $13.87 \%$.

- Regarding the exergetic analysis, the solar field was responsible for the most exergy losses and destruction in the system ( $85 \%)$. Moreover, it is important to state that the exergetic destruction from the sun to the receiver is the most significant. In the power block, the exergy destruction rate in the evaporator and condenser was, approximately, twice the rate of exergy destroyed in the turbine and that one lost in the condenser. The exergetic efficiencies achieved in the solar field, power block and overall system were 27.37; 54.45; and $14.89 \%$.

- The DNI variation showed that the higher DNI value, the better the system performance. Also, the HTF and ORC mass flow rates required by the system also enhanced with the DNI increasing. The overall power generated in the day chosen for this analysis was 2907 kWh.day ${ }^{-1}$.

\section{ACKNOWLEDGEMENTS}

This work was supported by Conselho Nacional de Desenvolvimento Científico e Tecnológico (CNPq) process number of 870379/1997-6. 


\section{REFERENCES}

Aboelwafa, O., Fatten, S.E.K., Soliman, A. and Ismail, I.M., 2018, A review on solar rankine cycles: Working fluids, applications, and cycle modifications, Renewable and Sustainable Energy Reviews, Vol. 82, pp. 868-885.

Bellos, E. and Tzivanidis, C., 2017, A detailed exergetic analysis of parabolic trough collectors, Energy Conversion and Management, Vol. 149, pp. 275-292.

Bellos, E., Tzivanidis, C., Antonopoulos, K.A. and Daniil, I., 2016, The use of gas working fluids in parabolic trough collectors - an energetic and exergetic analysis, Applied Thermal Engineering, Vol. 109 , pp. $1-14$.

Dudley, V.E., Kolb, G.J., Sloan, M. and Kearney, D., 1994, Test results: Segs ls-2 solar collector, Report of Sandia National Laboratory (SAND94-1884).

Fergani, Z., Touil, D. and Morosuk, T., 2016, Multi-criteria exergy based optimization of an organic rankine cycle for waste heat recovery in the cement industry, Energy Conversion and Management, Vol. 112, pp. 81-90.

Heller, P., ed., 2017, The Performance of Concentrated Solar Power (CSP) Systems: Analysis, Measurement and Assessment, Woodhead Publishing. ISBN 978-0-08-100517-0.

Kalogirou, S.A., 2012, A detailed thermal model of a parabolic trough collector receiver, Energy, Vol. 48, pp. 298-306.

Petela, R., 2003, Exergy of undiluted thermal radiation, Solar Energy, Vol. 74, No. 6, pp. $469-488$.

Ravi Kumar, K. and Reddy, K.S., 2012, 4-E (energy-exergy-environmental - economic) analyses of line-focusing standalone concentrating solar power plants, International Journal of Low-Carbon Technologies, Vol. 7, pp. 82-96.

Rayegan, R. and Tao, Y., 2018, A procedure to select working fluids for solar organic Rankine cycles (ORCs), Renewable Energy, Vol. 36, No. 2, pp. 659670.

Shu, G., Li, X., Tian, H., Liang, X., Wei, H. And Wang, X., 2014, Alkanes as working fluids for hightemperature exhaust heat recovery of diesel engine using organic rankine cycle, Applied Energy, Vol. 119, pp. 204-217.

Tchanche, B.F., Papadakis, G., Lambrinos, G. and Frangoudakis, A., 2009, Fluid selection for a lowtemperature solar organic Rankine cycle, Applied Thermal Engineering, Vol. 29, No. 11, pp. 2468-2476.

Yang, Y., Li, J., Yang, Z. and Duan, Y., 2019, Thermodynamic analysis and optimization of a solar organic Rankine cycle operating with stable output, Energy Conversion and Management, Vol. 187, pp. 459-471. 